\title{
Mentorsamtaler og professionel udvikling for nye lærere
}

\author{
Lisbeth Lunde Frederiksen, FoU-leder, VIA University College, \\ Iluf@via.dk \\ Elisabeth Halse, lektor, VIA University College, elha@via.dk
}

\begin{abstract}
Resumé
Artiklen præsenterer en empirisk undersøgelse af mentoring af nye lærere. I artiklen spørges til, hvad der henholdsvis befordrer og hæmmer at praktisere mentoring for nye lærere med fokus på professionel udvikling.

Mentoring på fire skoler i samme kommune blev fulgt et år. Skolerne var udpeget af kommunen ud fra parametre om forskellighed i forhold til størrelse og erfaringer med mentoring på skolen og ud fra villighed $\mathrm{i}$ at deltage i projektet.

Undersøgelsen viser, at ledelsens opmærksomhed på professionel udvikling, muligheden for observation, gruppementoring, hvordan man forstår mentors rolle, og udvælgelse af mentor herunder mentorkompetencer ser ud til at have betydning. Dette udfoldes i artiklen.
\end{abstract}

Nøgleord: nye lærere, induktion, mentor, professionel udvikling

\begin{abstract}
This article presents an empirical study on mentoring for newly qualified teachers, focusing on professional development. The study inquires into what enhances and hinders this mentoring practice.

The study followed mentoring at four schools within the same municipality. The schools were chosen by the municipality, on the basis of parameters such as differences in size, experience with mentoring and willingness to voluntary participation in the study.

The study finds, that the school leadership's attention to professional development, the possibility for observation, group mentoring, the understanding of the mentor's role, the selection of mentor candidates and an understanding of mentor competences seems to be of importance to the mentoring practice. These findings will be unfolded in the article.
\end{abstract}

Keywords: newly qualified teachers, induction, mentor, professional development 


\section{Indledning}

Hver fjerde lærer overvejer at forlade folkeskolen inden for de første år, og 14,4 procent af lærere mellem 25-29 år gør det (Christensen, 2019; Frederiksen et al., 2017). Der synes at være et stort behov for støttende forløb til lærere for at sikre den professionelle udvikling og for at fastholde lærerne i professionen (Britton et al., 2003; European Commission, 2010; Frederiksen, 2009).

Læreruddannelsen kan give de bedst mulige forudsætninger for at blive dygtige professionsudøvere, men nogle sider af professionsudøvelsen læres gennem efterfølgende praksis i professionen, og denne læring bør knytte an til systematisk vejledning (St.meld. nr. 11., 2009). For at understøtte den professionelle udvikling af de nye lærere, understreger Tonna et al. (2017), at refleksion er afgørende, særlig kritisk refleksion. Faglige og pædagogiske introduktionsforløb kombineret med mentorskab i de første år i professionen kan give strukturerede muligheder for, at nye lærere kan lære i og af praksis og derigennem støttes i den fortsatte professionelle udvikling (Frederiksen \& Lund, 2011; Jensen et al., 2000; New Teacher Center, u.å.).

EU-Kommissionens rapport fra april 2013 peger på mentoring som betydningsfuldt for at understøtte lærerkvalitet, og 15 medlemsstater har nu obligatoriske lærerstartsordninger til nye lærere (European Commission/ EACEA/Eurydice, 2013).

I Danmark har man ingen national ordning mht. lærerstartsordninger. I EVAs evaluering af de nyuddannedes møde med folkeskolen peges der på, at der er behov for tiltag (EVA, 2011), og dette er stadig aktuelt. Det kan ses i Lærerkommissionsrapporten fra 2019, hvor det anbefales, at skolerne arbejder med en mere systematisk modtagelse, gerne med mentoring (Christensen, 2019). Endvidere peger ekspertgruppen for evalueringen af LU13 på behovet for at styrke overgangen mellem læreruddannelsen og arbejdslivet, gerne gennem en systematisk lærerstartsordning med induktionsforløb (Styrelsen for Forskning og Uddannelse, 2018), og i en aftale om arbejdstid for lærere i kommunerne mellem KL og Lærernes Centralorganisation (KL \& Lærernes Centralorganisation, 2020) understreges det under bemærkninger til $\S 10$ at "der skal skabes rum for at nyuddannede kan reflektere over egen og andres praksis med henblik på udvikling i forhold til undervisningsopgaven."

I forskningsprojektet "Lærerstart og fodfæste" har vi tidligere gennem en spørgeskemaundersøgelse og fokusgruppeinterviews undersøgt, hvordan praksis møder nye lærere (Frederiksen et al., 2017; Rosholm, 2017). Vi kan 
på baggrund af undersøgelsen konkludere, at praksis modtager nye lærere meget forskelligt, men at nye lærere i et vist omfang tilgodeses med hensyn til rammerne for deres arbejde. Men kun 38 procent af 1140 respondenter i form af nye lærere svarede, at de havde haft én eller anden form for mentorstøtte. Yderligere undersøgte vi, om mentoren havde en eller anden form for kursus eller uddannelse i det at være mentor eller vejleder. Ud af de 38 procent af de nye lærere med mentorer havde 17 procent haft en mentor med en form for kursus eller uddannelse inden for vejlederområdet. Blandt disse var tendensen, at de i højere grad havde haft pædagogiske og didaktiske drøftelser, og de nye lærere følte sig signifikant bedre støttet end gruppen af nye lærere med mentorer uden uddannelse. Samtidig fremgår det af undersøgelsen, at nye lærere, der har haft uddannede mentorer, generelt vurderer mentorsamtaler med fokus på pædagogisk og didaktisk indhold meget højt (Frederiksen et al., 2017).

\section{Forskningsdesign}

\section{Forskningsspørgsmål og teoretiske tilgange}

Det fremgår af EU-Kommissionens rapport vedrørende lærerstartsordninger, at mentoring af nye lærere bør indeholde såvel personlig, social som professionel støtte (European Commission, 2010). International forskning fremhæver også, at specielt effektiv støtte med fokus på fortsat professionel udvikling reducerer følelsen af isolation, det styrker self-efficacy (European Commission, 2010), selvtillid, selvrefleksion og evnen til problemløsning (Korthagen \& Wubbels, 1995). Endvidere øges tilfredsheden med lærerarbejdet, når lærere reflekterer over egen undervisning, hvilket kan bidrage til fastholdelse (Frederiksen, 2016; Korthagen \& Wubbels, 1995).

Forskning viser, at meget af den støtte, som nye lærere får de første år i Danmark, ikke understøtter fortsat professionel udvikling, på trods af at de nye lærere ønsker kvalificerede didaktiske samtaler. Mange skoler og kommuner har først og fremmest fokus på socialisering ind i den lokale skolekontekst, klap på skuldrene og hurtig "ambulancehjælp" (Frederiksen, 2011; Frederiksen et al., 2017). Mentoring forstås i denne sammenhæng som en dialogisk samtale med en kritisk konstruktiv tilgang (Wang \& Odell, 2002; 2007).

I nærværende studie spørges der derfor til, hvad der henholdsvis befordrer og hæmmer at praktisere mentoring for nye lærere med fokus på professionel udvikling. 


\section{Professionel udvikling}

Projektet har med henvisning til ovenstående haft professionel udvikling, hvor refleksion står centralt, for øje og ud fra Rønnestads (2008) og Korthagen \& Wubbels (1995) forståelse. Rønnestad forstår professionel udvikling som tilegnelse af og ændring i kundskab og kompetence, som "endringer i profesjonell holdning, kognitiv og emosjonell fungering, interpersonlig fungering, profesjonell identitet, verdier og etikk, og forståelse av profesjonelle roller" (Rønnestad, 2008, s.279). Af centrale aspekter, som har betydning for professionel udvikling, fremhæver Rønnestad faglig nysgerrighed, videbegær, en kundskabssøgende holdning, en åbenhed for teori samt en forståelse af og bevidsthed om arbejdets kompleksitet i det professionelle arbejde, herunder tolerancen for flertydighed og evnen til at kunne udholde at forholde sig til sammensatte og komplekse problemstillinger i arbejdet. Det mest centrale enkeltstående aspekt ved professionel udvikling synes dog, ifølge Rønnestad, med henvisning til Korthagen \& Wubbels, at være at kunne opretholde en kontinuerlig refleksion, når man møder udfordringer, og det uanset niveauer af professionel erfaring. Rønnestad pointerer endvidere, at professionelle forandringer sker gennem refleksion over praksis, og opfattelser formes og ændres både i det reflekterende enerum og i dialog. Korthagen \& Wubbels (1995, s. 7) definerer refleksion som "the mental process of structuring or restructuring an experience, a problem or existing knowledge or insights." Refleksion indebærer altså at forholde sig kritisk til egen praksis med henblik på løbende at udvikle denne praksis. Det indebærer evnen til at analysere praksis og en årvågenhed over for vigtige aspekter samt at udtænke alternative beslutninger eller handlinger.

Yderligere har vi været inspireret af Kvernbekks begreb "førstehåndserfaringens autoritet" (2003, s. 165) i forbindelse med refleksion. Man tror, at man kan lave nemme koblinger fra førstehåndserfaringer (fra praksis) til vigtig professionel viden for praksis. Kvernbekks pointe er imidlertid, at sådanne førstehåndserfaringer har en del fejlkilder som fx lettilgængelige forklaringer, hverdagsforståelser af sammenhænge, eller at sammenfald i tid er lig med sammenhæng i forklaring. Fejlkilder, som teoriindsigt kan forhindre. Teorien skal således være med til at fastholde og udvikle komplekse forståelser af komplekse problemstillinger i en kritisk refleksion, hvorfor inddragelse af teori kan være vigtig i mentorsamtaler, der har fokus på professionel udvikling. Med dette in mente har vi været opmærksomme på, om teori er blevet inddraget i mentoringen med henblik på at kvalificere refleksion. 


\section{Empirisk design}

Artiklen bygger på et multiple casestudy af fire udvalgte skoler i en dansk kommune. Overordnet er studiet en del af et større studie baseret på den metodiske tilgang Design-Based Research (Cobb et al., 2003). Nærværende artikel baserer sig på forskningens tredje fase. Første fase bestod af problemidentifikation, gennem en landsdækkende survey-undersøgelse (Frederiksen et al., 2017), et fokusgruppeinterview om, hvordan praksis modtager nyuddannede lærere (Rosholm, 2017), et review af reviews (Frederiksen, 2020) samt et review om skolekultur (Frederiksen et al., 2019). Anden fase har bestået $\mathrm{i}$ at få mentorordninger som designprincip i gang på skoler, og tredje fase, dette multiple casestudy, omhandler afprøvning af mentoring i praksis.

I studiet om, i hvor høj grad mentorsamtaler havde mulighed for at have fokus på professionel udvikling, blev der valgt fire skoler af kommunen, med størst mulig variation mht. f.eks. størrelse, land/by og erfaring med mentorordninger på skolen. Det empiriske materiale bestod af:

- Logbogsnotater fra nye lærere (16) og mentorer (8)

- Forskernoter (10)

- 15 deltagende observationer (Spradley, 1980)

- Opstartsmøder med skoleleder og mentorer (4)

- Semistrukturerede interviews (Kvale \& Brinkmann, 2009) af nyuddannede lærere (7), mentorer (4) og skoleledere (4)

- Funktionsbeskrivelser for mentorordning på de involverede skoler (2).

Nogle af de observerede mentorforløb blev opfulgt med uformelle samtaler med mentorerne, i ønsket om at få kvalificeret mentorsamtalerne og at blive inspireret. Derudover har der forud for forløbet været foretaget et todages mentorkursus for alle kommunens mentorer med fokus på facilitering af refleksion i mentorsamtalerne, inklusive tre observationer.

\section{Analysestrategi og metode}

Undersøgelserne er blevet forenet under hermeneutisk ontologi og epistemologi, ved at vi har betragtet mentorsamtalerne som fænomener, der kun er tilgængelige for os i lyset af den horisont og forforståelse, vi er bærere af.

I analysen har vi arbejdet med en induktiv åben kodning mod en mere tematisk orienteret kodning for derefter at uddrage kategorier og temaer, 
som vi har vendt tilbage til og spurgt til i alle cases (Braun \& Clarke, 2006; 2013). Denne empiridrevne analyse har medvirket til, at de forskellige teorier, begreber fra øvrig forskning og litteratur ikke er blevet lagt ned over det empiriske materiale fra begyndelsen, men alene har tjent som inspiration og baggrund.

\section{Resultater}

I vores analyse af empirien fra de fire cases er vi kommet frem til fem temaer, der har betydning for, hvad der befordrer og hæmmer at praktisere mentoring for nye lærere, med fokus på professionel udvikling i mentorsamtalerne:

- Ledelsens opmærksomhed på professionel udvikling

- Muligheden for observation

- Gruppevejledning

- Mentorrollen - hvordan den kan forstås

- Udvælgelse af mentor, herunder mentorkompetencer.

I nedenstående udfoldes disse fem temaer med inddragelse af få begrænsede empiriudsnit.

\section{Ledelsens opmærksomhed på professionel udvikling}

Dette tema handler om ledelsens rolle, direkte som indirekte, i udførelsen af mentoring.

På de skoler, hvor man har en funktionsbeskrivelse for mentoring, og hvor ledelsen har haft fokus på professionel udvikling, ser det ud til, at man i højere grad bestræber sig på professionel udvikling i mentorsamtalerne. De fire cases placerer sig meget forskelligt mht. denne opmærksomhed. To skoler havde en funktionsbeskrivelse med bl.a. fokus på professionel udvikling, og to skoler havde ingen.

En af skolerne med formuleret funktionsbeskrivelse skiller sig markant ud ved stor bevidsthed om løbende professionel udvikling, ikke kun for nyuddannede, men for personalet generelt. Her har ledelsen og lærerkollegiet sammen udviklet et læringshjul, bl.a. inspireret af og baseret på et nordisk systematisk review om de vigtigste lærerkompetencer (Nordenbo et al., 2008). Alle lærere på skolen arbejder ud fra læringshjulet, både i skolens 
team og i de enkelte læreres undervisning, med henblik på at kvalificere og udvikle undervisningen.

Ud fra læringshjulet reflekteres der over og udvikles undervisning. Der tages udgangspunkt i hjulet i MU-samtaler, i skolelederens indledende samtaler med de nye lærere og i mentordagsordener. Det er ud fra læringshjulet, at man definerer god undervisning og god udvikling af undervisning. Læringshjulet dagsordensætter ligeledes teamarbejdet, arbejdet i læringsfællesskaber og mentorsamtaler. Med andre ord iscenesættes professionel udvikling med reference til læringshjulet og dette smitter også af på mentoringen. Her er der i langt højere grad fokus på den professionelle støtte, end hvad vi kan finde i det empiriske materiale fra de andre skoler. Skolelederen udtaler fx følgende:

\section{Altså, jeg vil fremhæve vores læringshjul, det der med de tre kompeten- cer i forhold til at være lærer. Relationskompetence, faglige og didakti- ske kompetencer, det er det, der gør den gode lærer..., hvis man kigger $i$ læringshjulet, så kan man jo som mentor være god til at spørge ind til det, så den ny lærer kan fä en refleksion over det, der er gjort, eller hvordan kan jeg komme videre med det her, eller hvorfor er det, at det er vokset mig over hovedet, hvordan kan jeg få den der kompleksitet ned, så jeg kan overskue det. (Skoleleder)}

Det ser ud til, at en eksplicitering af værdier og retning for skolens pædagogik og udvikling i kraft af udarbejdelse af et læringshjul kan være med til at understøtte mentorsamtaler med fokus på professionel udvikling. Samtidig kan der være en risiko for, at mentoring på denne vis også kan komme til at antage en meget deduktiv form, hvor teori og værdier kan blive styrende for samtalens indhold frem for de nye læreres aktuelle oplevede udfordringer, der kunne ligge uden for læringshjulet.

\section{Muligheden for observation}

Temaet omhandler mulighederne ved at inddrage observation i forbindelse med mentoring. Analysen viser, at brug af observation ikke er fremtrædende i casene, men der, hvor det bliver brugt, giver det mulighed for refleksion og faglige dialoger om undervisning. Empirien peger på, at observationer har været fundament for efterfølgende mentorsamtaler, de har været første tiltag mod refleksioner over undervisning og dermed første skridt mod professionel udvikling. 
En ny lærer, der er blevet tilbudt observation både af egen, peers og erfarne læreres undervisning, finder observationen særdeles givende og siger f.eks.:

Det [observation] kunne jeg måske godt tænke, at der havde været meget mere af det her forste år, at der havde været mere tid til, at man kunne komme ud og se andre larere og eksempelvis $i$ de fag, man selv har. (Ny lærer)

Samtidig er mentor også opmærksom på, at de nye læreres observation af mentors undervisning skal føre til en samtale om, hvordan de kan bruge observationerne til egen undervisning, således at der ikke blot bliver tale om imitation. Mentor siger fx:

Fint nok, vi kan jo godt gå timen igennem med, hvad jeg gjorde, men det er mere interessant, hoad X kan bruge det til? At hun kan forbinde dette til sin egen undervisning. (Mentor)

\section{Gruppevejledning}

Temaet har fokus på mulighederne ved at være flere nye lærere i mentoring-seancerne. Vores empiri viser, at det at være flere nye lærere i samme samtale (gruppevejledning) understøtter en undersøgende dialog, specielt hvis det foregår på basis af observationer. En af de nye lærere siger bl.a. følgende om dette:
Ja, altså, så dukker der også et eller andet op, hois Y [den anden nye lærer] sidder og siger et eller andet, så har jeg et eller andet at tilføje, det er tit, man ikke lige kommer i tanke om det, hvis det bare er én selv, der bare sidder og snakker. (Ny lærer)

Den undersøgende dialog understøttes i endnu højere grad, når der kobles forskellige former for observation til (peers, mentor). En ny lærer har følgende kommentar:

Men det gav rigtigt meget, det der med at vi var nede og se hinanden undervise. Det kunne jeg godt have savnet, at vi var blevet ved med, det kunne vi godt have lavet noget mere af. Men det hjalp rigtigt meget. Det kan hurtig blive en snak, hois man ikke helt konkret har set det, 
men når hun så er nede og se, så kan man virkelig sige okay, hvad helt konkret, hoad skete der i undervisning osv. (Ny lærer)

Mentoren uddyber dette ved at pege på, at observation og gruppedrøftelser giver flere nuancer og dermed anledning til refleksion de nye lærere imellem:

\section{Det giver mere dynamik, at man har to personer, som har varet inde og kigge på hinandens undervisning, så man kan tage fat $i$ noget der... de kan også ligesom sparre med hinanden, og når den ene kommer ind på et eller andet, så kommer den anden også i tanke om noget. Det gør man ikke, hois man sidder en til en, så kører man måske mere i den samme rille. (Mentor)}

\section{Mentorrollen}

Temaet har fokus på de meget forskellige forståelser eller praktiseren af mentorrollen, der både kan bero på en usikkerhed i mentorrollen, men også på divergerende opfattelser af, hvad en mentor egentlig skal, både fra skolens og mentorens side. Forståelsen af mentorrollen strækker sig over et kontinuum, fra at være en god kollega til en kollega, der aktivt og bevidst understøtter den professionelle udvikling. En god kollega er en, man altid kan komme til, hvis man har brug for hjælp - her er der tale om en venlig, men passiv mentorrolle. En mentor med fokus på professionel udvikling er opsøgende og igangsættende og arbejder systematisk for at etablere et refleksionsrum i en samtænkende relation. Endvidere ser denne mentor også mulighed for selv at udvikle sin egen praksis gennem mentorsamtalerne.

Mentorrollen udføres meget forskelligt i de fire cases. Der er eksempler på, at hverken mentor eller den nyuddannede lærer har vidst, hvad de skulle bruge mentorsamtalerne til, hvilket har påvirket antallet af mentorsamtaler og indholdet. En forsker, der efter en mentorsamtale drøftede med mentor og den nye lærer, hvad en sådan samtale kan indeholde, skrev følgende i sit notat:

... mentor er klar over, at mentor skal rammesætte samtalen, men er meget usikker på, hvad en mentorsamtale kan indeholde. Og spørger om, hoad der ellers kan stå på sådan en dagsorden. Jeg fornemmer en usikkerhed i mentorrollen. (Forskernotat) 
Når mentorrollen forstås som en god kollega, er mentorsamtalerne primært fokuseret på praktiske ting og tips and tricks. Tematikkerne centreres omkring hverdagens små udfordringer og hændelser, og er ofte kortsigtede.

En ny lærer fortæller f.eks. om, hvordan samtalen med mentor hjalp med at få overblik over daglige opgaver. En anden ny lærer giver udtryk for, at hun har fået konkrete råd:

\section{Der snakkede vi om helt konkret, hoad kunne jeg? Hun sagde, jamen så sig sådan i den her rækkefølge "at de skal være stille", "de skal rejse op" osv. Altså, hvordan jeg skulle gøre det, og det var noget, jeg gik ned og gjorde, og så har jeg gjort det siden. (Ny lærer)}

Ingen af samtalerne af ovenstående karakter viste tegn på facilitering af refleksion med henblik på løbende at udvikle sig,

Denne form for mentoring kan til tider være relevant og gavnlig for dén nye lærer, hvis værdier og holdninger er sammenfaldende med mentors. Der kan dog være risiko for, at mentoringen på den måde fører til konserverende undervisningsforståelse og praksis. For at mentorsamtalerne skal få et mere langsigtet perspektiv og være grobund for en professionel udvikling, kræves der også kritisk refleksion over og bevidsthed om undervisningsforståelser, læringssyn og egen praksis. Sådanne samtaler er vanskeligere, de kræver aktiv viden inden for feltet og fordrer en mere systematisk tilgang til mentoring. Denne type samtaler er der ikke så meget af $\mathrm{i}$ de fire cases. Nedenstående eksempel kan dog ses som ansaster til dette. En ny lærer siger:

\section{Så har vi jo læringshjulet her på skolen. Hvor der har været fokus på relationskompetence, og så har der været fokus på de didaktiske kom- petencer, klasseledelse, og så har vi snakket lidt om, hver gang har vi kunnet komme med problemstillinger, vi har haft, og så har vi, hvis vi nu havde relationskompetence på papiret, eller som vi nu skulle snakke om. Så har det været sådan, at hun [mentor] har kørt det over i det og snakket om, jamen hoor er vi så henne i denne cirkel og sådan noget. (Ny lærer)}

De mentorsamtaler, der har bevæget sig væk fra her og nu-problemstillinger og ind i et mere reflekterende rum, oplever både mentor og ny lærer som gavnlige, og den nye lærer oplever her også at kunne bidrage med noget af værdi. En ny lærer siger f.eks.: 
Jeg føler mig værdsat. Jeg føler mig ikke ny som sådan. Jeg føler ikke, man føler sig stemplet som ny. Man kommer med noget viden, der er vigtig. (Ny lærer)

Jeg synes, det er super rart, at der er en, der sætter sig helt ud og stiller nogle kritiske spørgsmål til det, man har gjort, oplevet og det, man tænker på. Det synes jeg, man kan komme til at reflektere meget over. (Ny lærer)

Og mentoren får også udbytte af samtalerne:

Ja, og så bliver jeg opmærksom på, at man altid udvikler sig, selv når man er nået pensionsalderen. Ja, jeg lærer jo også noget af dem, der er også noget den anden vej rundt. Så, ja. Meget givende. (Mentor)

På én skole opereres der med flere forskellige former for vejledning: En mentor for den nye lærer og en faglig vejleder, der er sparringspartner for såvel nye lærere som andre kolleger i (fag)faglige spørgsmål. Derudover forventes de nye læreres team også at være vejledere, specielt i forhold til personlig og social støtte. En skoleleder siger:

... så er der jo også alt det praktiske som ny lærer, men det er jo teamets opgave. Det er jo ikke kun mentor, det her, det er teamets opgave, og det ved de også godt, det får de også at vide, at de har en opgave. (Leder)

Mentorens opgave er at facilitere udvikling af den nye lærers refleksionskompetence over konkret praksis, så den nye lærer på sigt selv kan tackle og udvikle undervisning. Forskellen i forståelse af mentorrolle ser ud til i de fires cases at afhænge af, om der er et systematisk fokus på professionel udvikling på skolen, og af tydeliggørelse af mentorrollen gennem en funktionsbeskrivelse.

Til trods for tegn på reflekterende mentorsamtaler bar alle samtaler præg af meget lidt åbenhed for teori og for samspil mellem den teoretiske og den erfaringsbaserede viden, uanset opfattelse af mentorrolle. Noget tyder på, at mentorerne ikke i særlig høj grad ser deres rolle som den, der skal skabe sammenhæng mellem uddannelse og professionen. I empirien er der ingen eksempler på, at de nye læreres erhvervede teori fra uddannelsen sættes i 
spil i forhold til praksiserfaringer. Anvendelse af teori som fundament for en professionel udvikling er stort set ikke tilstede. Dermed ser vi en risiko for, at den nye lærer frakobles en del viden og færdigheder tilegnet i læreruddannelsen og primært kobler sig til den praksiskultur, der er ved den skole, hvor den nye lærer får sin første ansættelse. En ny lærer udtaler i et interview følgende:

\section{Alt det teoretiske, som jeg jo synes har været vildt fedt at norde i. Det er man jo selv skyld $i$, at det glider lidt ud eller sådan, det fär man $i$ hoert fald ikke aktivt brugt. Jeg tænker altså, man trækker jo på meget af det ubevidst, ikke også, fordi man har haft så meget, men aktivt bruger man det jo ikke så meget... (Ny lærer)}

\section{Udvælgelse af mentor, herunder mentorkompetencer}

Temaet handler om, hvilken betydning afstanden mellem mentor og den nyuddannede lærer har for, at der kan foregå kvalificerede, reflekterende dialoger i mentorsamtalen.

I de fire cases har der været forskellige strategier for, hvem man har valgt som mentor. På to af skolerne har kompetencer været princippet for udvælgelse, dvs. hvem, der ville være kvalificeret til at udføre opgaven og havde interesse i funktionen, samt at mentoren ikke var en del af det daglige samarbejde med nye lærer. På én skole har det været nærhedsprincippet, der har været afgørende, og på den sidste skole har både kompetence- og nærhedsprincippet været i spil.

Empirien viser, at nyuddannede lærere kan se en fordel $i$ at have en mere "neutral" mentor, som de ikke arbejder sammen med til hverdag, hvorfor de kan bringe emner op, der går lidt tæt på i forhold til elever, forældre eller kolleger:

\section{... en person, som man måske ikke snakker så meget med til dagligt, men som man kan tale med om lidt af hvert og måske også noget af det, der er lidt tæt på, øhm - kollegamæssigt eller elevmæssigt... ( $\mathrm{Ny}$ lærer)}

At mentor ikke er en del af hverdagens praksis, kan give den nye lærer mulighed for at åbne sig mere. 
I en af casene oplever de nye lærere det som meget opløftende og understøttende for deres professionelle udvikling, at deres mentor er uddannet og valgt på baggrund af kompetencer. F.eks. udtaler en ny lærer følgende:

\section{Det er super rart, at der er én, der sætter sig helt ud og stiller nogle kritiske spørgsmål til det, man har gjort, oplevet og det, man tænker på. Det synes jeg, man kan komme til at reflektere meget over. Det var en god løsning, at det ikke er en, man går med til daglig ... måske lagger [hun] vægt på nogle helt andre ting. (Ny lærer)}

I citatet peger læreren på mentor som en slags kritisk ven, hvor samtalen har en anden karakter end hverdagssnak. Det vurderes, at der arbejdes med en professionel udvikling som noget andet end blot at give et klap på skulderen og konkret rådgivning.

To af skolerne har haft nærhed som princip for udvælgelse af mentoren, hvilket kan være vanskeligt, idet det er svært at skabe distance til den hverdagspraksis, som begge er involverede i. I en af disse cases er mentor blevet bevidst om, at en mentor fra en anden position ville kunne udfordre den nye lærer bedre og dermed i højere grad facilitere refleksioner. Mentor siger f.eks.:

\section{Fordi jeg tænker, de [mentorer med distance] kan spørge mere åbent ind til. Jeg tager mange ting for givet og de små samtaler, der, hvor vi siger "Går det godt?" "Ja, det går godt" og sådan. Jeg tænker, at en udefra ville kunne gøre det anderledes. (Mentor)}

Når den nyuddannede lærer skal reflektere over en fælles praksis sammen med mentor, er der stor chance for, at mentor også kommer til at undersøge egen praksis, hvilket kan være berigende, men også en situation, hvor mentor kan føle sig utryg.

Også den nye lærer kan se udfordringer i sammenblandingen af kollegaog mentorrollen:

\section{[Mentor] er også den kollega, jeg har som nærmeste kollega. Så er det også lidt svært, hvornår er det så en mentor, hoornår er det bare en kollega, man ville spørge? (Ny lærer)}


Meget i empirien tyder på, at både mentor, den nyuddannede lærer og skolen her har en forståelse af, at formålet med mentoring er personlig og social støtte, herunder rådgivning, snarere end facilitering af refleksion med henblik på professionel udvikling, og i den sammenhæng kan en mentor tæet på måske være god. Men der kan også være tale om, at mentor, her tæt på, har svært ved at påtage sig rollen som igangsætter af en undersøgende dialog, der kan giver anledning til kritisk refleksion og udvikling af praksis, netop fordi denne er tæt på.

\section{Konklusion}

Udfordringer og muligheder, hvad angår at facilitere professionel udvikling i mentorsamtaler med nyuddannede lærere, drejer sig bl.a. om en eksplicitering og en bevidsthed hos såvel skoleleder, mentorer som hos de nyuddannede lærere om mentorsamtalernes hensigt og mentorens rolle. En eksplicitering og formalisering, f.eks. gennem en funktionsbeskrivelse, kan bidrage til dette.

Et tydeligt værdigrundlag og eksplicitering af skolens pædagogik og retning for pædagogisk arbejde kan bidrage til en øget opmærksomhed på professionel udvikling i skolekulturen, der så igen får betydning for, at fokus drejes mod også professionel udvikling i mentorsamtalerne.

Rammer, der giver muligheder for forskellige former for observation som udgangspunkt for mentorsamtaler, hjælper med at dagsordensætte pædagogiske og didaktiske samtaler i mentorsamtalerne og understøtter en undersøgende dialog, der kan bidrage til refleksion og dermed give mulighed for at facilitere professionel udvikling. Også gruppevejledninger bidrager til dette.

Ikke alle mentorer udpeges ud fra et princip om besiddelse af mentorkompetencer, men derimod ud fra et nærhedsprincip. Mentorer med vejledningskompetencer ser ud til i højere grad at kunne bidrage til facilitering af professionel udvikling, kompetencerne gør dem i stand til at facilitere refleksion over undervisning og komme videre end "hverdagssnak".

Mentorer, uanset kvalifikationer, ser ikke deres rolle som nogle, der skal skabe sammenhæng mellem uddannelse og profession, dette giver sig bl.a. udslag $\mathrm{i}$, at der ikke inddrages teoretiske perspektiver på udfordringer i samtalerne eller i drøftelser, hvad de nye lærere forstår ved god undervisning, og hvilke resurser de har med sig fra uddannelsen. 
På de skoler, hvor man har valgt en mentor "tæt på", synes der at være en forståelse af mentoring primært som social og personlig støtte og ikke som støtte til professionel udvikling. Mentorer tæt på den nye lærers praksis har sværere ved at distancere sig fra praksis, og den nye lærer har sværere ved at skelne mellem mentorrollen og kollegarollen. Hermed er det sværere at etablere et reflekterende rum som fundament for professionel udvikling.

Mentorer, der ikke er tæt på den nyuddannede lærers praksis, opleves i nogle tilfælde at invitere den nyuddannede lærer til større åbenhed om mere sårbare emner.

Analysen peger i retning af, at skolekulturen har stor betydning for muligheden for at udføre mentoring med fokus på refleksion og dermed muligheden for fortsat professionel udvikling. En kultur, der generelt er bevidst om professionel udvikling, vil også i højere grad have mulighed for at implementere mentoring, der ikke kun har fokus på social og personlig støtte, men også på støtte, der kan hjælpe til refleksion og dermed fortsat professionel udvikling. Hvis en mentor ikke understøttes af ledelse og skolekultur til at fokusere på professionel udvikling, kan det være svært at implementere.

International forskning peger på, at en samarbejdende skolekultur er vigtig, også når man taler om mentoring med fokus på professionel udvikling. I den sammenhæng peges der på en understøttende, interesseret og anerkendende ledelse som en afgørende faktor for at udvikle en sådan skolekultur (Frederiksen \& Halse, 2020). Vores empiri i nærværende projekt viste et godt eksempel på, at netop eksplicitering af skolens fælles udviklede pædagogik og udviklingsretning, kombineret med en støttende, interesseret ledelse, kan være med til at støtte processen med professionel udvikling i mentoring.

Ligeledes understøtter nærværende studie tidligere forskning omhandlende mentorers vejledningskompetencer som vigtig for udøvelse af mentoring med fokus på professionel udvikling. Adskillige internationale studier peger på, at mentoring med en ikke-uddannet mentor er væsentlig forskellig i kvalitet fra en mentoring med en uddannet mentor (Glassford \& Salinitri, 2007; Hobson et al., 2009; Spooner-Lane, 2017), og at mentoring af en ikke-uddannet mentor kan føre til "judgementoring" (Hobson \& Malderez, 2013). 


\section{Referencer}

Braun, V., \& Clarke, V. (2006). Using thematic analysis in psychology. Qualitative Research in Psychology, 3(2), 77-101. https://doi.org/10.1191/1478088706qp063oa

Braun, V., \& Clarke, V. (2013). Successful Qualitative Research: A Practical Guide for Beginners. SAGE.

Britton, E., Paine, L., Pimm, D., \& Raizen, S. (red.) (2003). Comprehensive teacher induction. Kluwer Academic Publishers.

Christensen, P. B. (2019). Lærerkommissionens rapport. https://www.dlf.org/media/12970722/ laererkommisionsrapporten.pdf

Cobb, P., Confrey, J., Disessa, A., Lehrer, R., \& Schauble, L. (2003). Design Experiments in Educational Research. Educational Researcher, 32(1), 9-13. https://doi.org/10.3102/0013189X032001009

European Commission/EACEA/Eurydice (2013). Key data on teachers and school leaders in Europe, 2013 Edition. Eurydice Report. https://doi.org/10.2797/91785

European Commission (2010). Developing coherent and system-wide induction programmes for beginning teachers - a handbook for policy makers. https://ec.europa.eu/assets/eac/education/policy/school/doc/handbook0410_en.pdf

EVA (2011). Læreruddannelsens faglige kvalitet. Danmarks Evalueringsinstitut.

Frederiksen, L. L. (2009). Mentorskab i folkeskolen. Liv i Skolen, 2, 59-64.

Frederiksen, L. L. (2011). Hvad ved vi? Hvad vil vi? Hvad gør vi? Unge Pædagoger, 2, 3-13.

Frederiksen, L. L. (2016). Mentoruddannelse for 50+'ere. I: Frederiksen, L. L., \& Hedegaard, K. M. (red.), Veje til professionel udvikling: i læreruddannelse og lærerarbejde (s. 107-122). Klim.

Frederiksen, L. L. (2020). Support for newly qualified teachers through teacher induction programs - a review of reviews. I: Olsson, K. R., Bjerkholt, E., \& Heikkinen, H. (red.), New teachers in the Nordic Countries - ecologies of mentoring and induction. Cappelen Damm Akademisk.

Frederiksen, L. L., \& Halse, E. (2021). Uddannelse til kompetente mentorer for nyuddannede lærere

. Manuskript indsendt til udgivelse.

Frederiksen, L. L., Halse, E., \& Jensen, I. R. (2019). Skolekultur, lærerstart og fodfæste. Studier i Læreruddannelse og -Profession, 4(1), 207-227.

Frederiksen, L. L., Krøjgaard, F., \& Paaske, K. A. (2017). Lærerstart og fodfæste $i$ et livslangt karriereforløb. VIA University College. https://www.ucviden.dk/da/publications/ lærerstart-og-fodfæste-i-et-livs-langt-karriereforløb

Frederiksen, L. L., \& Lund, J. H. (2011). Dimittendundersøgelse Læreruddannelsen i Århus, rapport 2, årg 2009. I: Læreruddannelsen i Århus, rapport 2, dimittendårgang 2009. Læreruddannelsen i Århus, VIA University College.

Glassford, L. A., \& Salinitri, G. (2007). Designing a Successful New Teacher Induction Program: An Assessment of the Ontario Experience, 2003-2006. Journal of Educational Administration, 60, 1-34.

Hobson, A., Ashby, P., Malderez, A., \& Tomlinson. (2009). Mentoring Beginning Teachers: What We Know and What We Don't. Teaching and Teacher Education, 25(9), 207-216. https://doi.org/10.1016/j.tate.2008.09.001

Hobson, A., \& Malderez, A. (2013). Judgementoring and other threats to realizing the potential of school-based mentoring in teacher education. International Journal of Mentoring and Coaching in Education, 2, 89-108. https://doi.org/10.1108/IJMCE-03-2013-0019

Jensen, J. B., Nielsen, N. G., \& Hansen, H. (2000). Fra læreruddannelse til lærerarbejde. Unge Prdagoger, $3 / 4$. 
KL, \& Lærernes Centralorganisation (2020). Aftale om arbejdstid for undervisere $i$ kommunerne. https://www.kl.dk/media/25184/o20-5032-aftale-om-arbejdstid-for-undervisere-i-kommunerne.pdf

Korthagen, F. A. J., \& Wubbels, T. (1995). Characteristic of reflective practitioners: towards an operationalization of the concept of reflection. Teachers and Teaching: Theory and Practice, 1(1), 51-72. https://doi.org/10.1080/1354060950010105

Kvale, S., \& Brinkmann, S. (2009). Interview : introduktion til et håndværk (2. udg.). Hans Reitzels Forlag.

Kvernbekk, T. (2003). Erfaring, praksis og teori. I: Kvernbekk, T. (red.), Pædagogik og lærerprofessionalitet (s. 146-163). Klim.

New Teacher Center (u.å.). Our approach. Hentet d. 19. september, 2018, fra: https://newteachercenter.org/our-approach/

Nordenbo, S. E., Larsen, M. S., Tiftikçi, N., Wendt, R. E., \& Østergaard, Ø. (2008). Teacher competences and pupil achievement in pre-school and school. A systematic reveiw carried out for the Ministry of Education and Research, Oslo. Danish Clearinghouse for Educational Research, Danmarks Pædagogiske Universitetsskole, Aarhus Universitet.

Rønnestad, M. H. (2008). Profesjonell utvikling. I: Molander, A., \& Terum, L. I. (red.), Profesjonsstudier (s. 279-292). Universitetforlaget.

Rosholm, K. (2017, 25. august). Focus group interviews in Herning: Findings. https://www.ucviden.dk/da/publications/focus-group-interviews-in-herning-findings

Spooner-Lane, R. (2017). Mentoring beginning teachers in primary schools: research review. Professional Development in Education, 43(2), 253-273. https://doi.org/10.1080/19415257.2016.1148624

Spradley, J. P. P. (1980). Participant observation. Harcourt Brace College Publishers.

St.meld. nr. 11. (2009). Læreren: rollen og utdanningen. Kunnskapsdepartementet. https:// www.regjeringen.no/contentassets/dce0159e067d445aacc82c55e364ce83/no/pdfs/stm200820090011000dddpdfs.pdf

Styrelsen for Forskning og Uddannelse (2018). Kvalitet og Relevans i Læreruddannelsen. Ekspertgruppens evaluering og vurdering af læreruddannelsen af 2013. https://ufm.dk/publikationer/2019/evaluering-af-laereruddannelsen

Tonna, M. A., Bjerkholt, E., \& Holland, E. (2017). Teacher mentoring and the reflective practitioner approach. International Journal of Mentoring and Coaching in Education, 6(3), 210-227. https://doi.org/10.1108/IJMCE-04-2017-0032

Wang, J., \& Odell, S. J. (2002). Mentored Learning to Teach According to Standards-Based Reform: A Critical Review. Review of Educational Research, 72(3), 481-546.

Wang, J., \& Odell, S. J. (2007). An alternative conception of mentor-novice relationships: Learning to teach in reform-minded ways as a context. Teaching and Teacher Education, 23(4), 473-489. https://doi.org/10.1016/J.TATE.2006.12.010 